\title{
Continuing Education for Teachers in the Teaching Residency Program at Colégio Pedro II in Brazil
}

\author{
Neide F. P. Sant'Anna, Francisco R. P. Mattos*, Christine S. Costa \\ MPPEB, Colegio Pedro II, Rio de Janeiro, Brazil \\ Email: ${ }^{\star}$ Francisco.mattos@gmail.com
}

How to cite this paper: Sant'Anna, N. F. P., Mattos, F. R. P., \& Costa, C. S. (2017). Continuing Education for Teachers in the Teaching Residency Program at Colégio Pedro II in Brazil. Creative Education, 8, 1173-1192.

https://doi.org/10.4236/ce.2017.88084

Received: February 11, 2017

Accepted: June 30, 2017

Published: July 3, 2017

Copyright $(9) 2017$ by authors and Scientific Research Publishing Inc. This work is licensed under the Creative Commons Attribution International License (CC BY 4.0).

http://creativecommons.org/licenses/by/4.0/

\begin{abstract}
This article discusses the Teaching Residency Program of Colégio Pedro II, which features as a realization of Third Space in the qualification of teachers. The program is a reality of interaction between academic research and teaching practice, employing the experience in a public school to enhance the quality of teaching actions in the school realities of the participants, contributing to both to improve the quality of professional training of residents and to provide a discussion of the educational context. Four basic classes of conflicts experienced by recently graduated teachers, and such conflicts are analyzed with support on concept of Third Space.
\end{abstract}

\section{Keywords}

Continuous Training, Teacher Improvement, Third Space, Teaching

Residency Program

\section{Introduction}

In Brazil, inefficiency in education is reflected in pronounced social inequalities. This has provided a motivation for the development of recent public efforts in the educational field, especially for the creation of the Development Plan for Education (Brazil Ministry of Education, 2007) whose main pillars are teaching training and valuation of education professionals. PDE establishes objectives and guidelines that assert Government's commitment to the initial training of teachers in basic education public systems through the Universidade Aberta do Brasil (Open University of Brazil)- $\mathrm{UAB}$ - and Institutional Initiation to Teaching Study Grants Program-PIBID.

A traditional public institution named Coordination for the Improvement of University Level Personnel (CAPES) was then involved in fostering the training 
of university-level personnel to take action not only at university levels but in all educational levels. "UAB and PIBID, in their turn, alter the current structure for teacher training by establishing a permanent relationship between university education and basic education. It is the embryo for a future public national teacher training system in which federal government, through CAPES, finally takes on, what has always been, strictly speaking, its responsibility" (PDE, p. 15).

As a result of this institutionalization, the programs proposed in the PDE take on the dimension of long term State programs, instead of actions historically based on one-dimensional and temporary agreements. Other strategies aimed at improving the efficiency of classroom professionals, as well as instruments providing for more efficient actions in different environments, are being designed to mitigate many of the problems that afflict Brazilian Basic Education.

Within this context, Colégio Pedro II (CPII) has drawn up a project to share its successful experiences in Basic Education. The project aims at contributing to the improvement of teaching through continued training. It is called the CPII Teaching Residency Program-PRD. The main objective of PRD is to make the transfer of empirical teaching knowledge acquired through experience possible in a school that has produced good results. It also provides a platform for gaining experience, reflection, experimentation and knowledge among peers.

PRD is based on a sui generis structured specialization course. It is financed by CAPES and seeks to make the accumulated teaching expertise of CPII to teachers available who have just finished their undergraduate courses or have just started teaching in public schools.

The project's format provides for the interaction between the specific training that the resident teacher brings and the experience of an academic supervisor involving different classroom teaching practices. The Program makes use of public calls and agreements signed with State Education Offices, establishing logistics for the execution of activities similar to a supervised training course. This includes preparing reports, making lists of teaching materials and participating in the institution's research programs.

Providing the opportunity for beginning teachers to relate what they learned during their initial training to practical professional teaching experience is one of the pillars of the Program. Such interaction involves specific conceptual subjects as well as questions related to the social integration between students and student-teachers.

In this way, the Program takes the difficult task of associating or suiting the skills and knowledge acquired during the teacher's initial training as an undergraduate student to actual classroom practice and experience under real classroom conditions. Thus, it faces the fact that

“... the occasions are rare when the (teacher's) theoretical training does not have to be complemented by practical training, that is, by actual teaching experience of variable duration. This makes the teacher gain familiarity with his work environment and gradually enables him to acquire the skills he needs for the execution of his tasks" (Tardif \& Raymond, 2000: p. 211). 
In the case of school practices, an important factor in the teacher's development is the support that comes from more experienced educational professionals-all of which contributes to develop the beginning teacher's profile in his school work. In most cases, the transformation from student to de facto teacher includes a transition period based mainly on models that are learned during the resident's training, or on ideas he nurtures during this period. To take on his new role and come to grips with real situations that may be very different from his experiences as a student, he must develop new stances and attitudes and redirect his skills so that they meet the different demands that face a young teacher. One of the basic steps in the formation of a teacher is acquiring a new stance is the promotion of reflexive thinking, of well thought-out, analytic acts, replacing mere repetition of actions learned or received during initial training by actions that arise from reflection and questioning.

The practice of reflexive thinking carried out by a teacher, by itself, has its limitations, as pointed out by Garrido and de Carvalho (1999).

"On interpreting teaching situations and making decisions, a teacher makes use of 'alternative representations' which prove to be resistant to change. Without a partner who takes on the task of questioning and provoking in a systematic and well thought-out manner, inciting the professor to make changes, reflection alone on the part of the teacher would make progress difficult. The presence of the teacher-professor in beginning training courses, or of the researcher in service training, is important in stimulating changes in teaching practices by providing support and contexts, and by keeping track of the process of change before it is carried out by the student teacher" (Garrido \& de Carvalho, 1999: p. 153).

Contemplating all these requirements, PRD has been planned as a Third Space, in the sense of Zeichner (2010). The educational space provided by it intends to be a special place for experience and experimentation, for active observation, aimed at building new knowledge in the field of teaching by having the student teacher exposed to new theories, new practices and new ways of looking at age-old tasks of teaching and learning. The premises, procedures and components of the Program will be presented and discussed in this article.

\section{The Third Space in Continued Teacher Training}

The basic theoretical foundation of PRD is the concept of Third Space (Zeichner, 2010). The extension of the of Third Space to the educational field takes into account the interfaces between the academic field and real school conditions, where synergies are developed between concrete experiences and theoretical ideas, between elaboration of concepts and practical experiences.

The Third Space comes from the theory of Hybridity (Bhabha, 1990, 1994) which acknowledges the fact that

"individuals make use of multiple discourses in order to make sense of the world; it involves the rejection of opposing ideas between those coming 
from the academic field and those that have to do with practical knowledge. He then seeks new ways to explore what is seen as competing discourses, where disjoint perspectives of the type 'or' are transformed into points of view of the type "both/also"' (Zeichner, 2010: p. 92).

This theory has been employed in geography, arts, post-colonial and feminist studies, and more recently, in education (for example, Gutierrez, 2008; Moje et al., 2004; Soja, 1996) and also in teacher training (Cochran-Smith \& Lytle, 1999; Williams, 2014).

In the field of education, it achieves the objectives of improving teacher training and expanding the teacher's capacity to learn from practice, promoting scientific research in education by increasing interaction among educational professionals, administrators and researchers.

The current dominant model in teacher training is characterized by a dichotomy between learning the educational theory taught in universities, and making use of these theories in actual school teaching. Future teachers start teaching by "practicing" what they learned in their university courses. Another feature of this model is the discrimination against knowledge acquired by actual classroom teaching, so much so that research conducted in universities ignores whatever academic knowledge may come from actual school teaching. Furthermore, even in the academic field, educational research is regarded as aiming at professional development instead of at knowledge-building.

This situation can be explained by the lack of incentives for permanent members of university teaching staff to spend time in coordinating field activities, including those involving teaching practices by student teachers, on the one hand, and the right to interfere in outside institutions, on the other (Bullough et al., 1997, 2004; Cornbleth \& Ellsworth, 1994; Zeichner, 2002).

Although many programs include field experiments in their curricula, the length of time student teachers spend in schools is generally not carefully planned. Zeichner (1996) observes that the process of scheduling practice teaching is often "outsourced" to a central administrative office instead of being based on department needs. The scheduling is then done based on administrative considerations and not on the learning requirements of future teachers. Teachers-to-be are often left to their own devices receiving little guidance, so that good teaching practices are often acquired by chance instead of being learned in an organized manner (Darling-Hammond, 2009; Valencia et al., 2009).

Zeichner (2010) highlights experiences designed to reduce the distance between theory and practice in the University of Wisconsin-Madison (Labaree, 2004; Vick, 2006) by bringing experienced teachers to contribute in planning and evaluating University activities. In the same direction goes the work done by the Carnegie Foundation for Advancement of Teaching of producing video films on teaching practices and making them available on the internet (Pointer-Mace, 2009). These video films serve as a basis for each university to design websites for the use of its students. Other examples, mentioned by Gallas (2004), provide for the inclusion of subjects in the teacher training curricula that require the 
student to study articles published by classroom teachers about teaching practices in different levels of instruction.

There are also examples where part of the university course is done in school classrooms. Zeichner (2010) cites the University of Washington in Seattle where half of the Mathematics classes are taught in school classrooms where specific methodology learned at the university is being put into practice. During these classes, the classroom teacher's experiences are discussed.

Significantly extending these experiences, the practices in teacher training that involve the concept of Third Space constitute an epistemological paradigm change. It is within this new paradigm that the Teacher Residency Program has been developed. Its main features are presented in the next topics.

\section{The Concept of Teaching Residency}

University courses involving professions that require practical experience to build the bridge between theoretical knowledge and its application to real life situations must provide for the students' immersion in professional situations during their university course. This is perhaps best exemplified by Medicine courses, in which future professionals take part in hospital activities during a great part of their university time, at the end of which they are encouraged to specialize in a particular line of medicine during what is called the residency period. The fierce competition for acceptance in medical residency courses in important medical centers is a well-known fact in Brazil and the importance of this training period is widely acknowledged. This phase is characterized by

"the gradual taking on of responsibility in professional actions; the development of the capacity to take initiatives, to judge and assess, to internalize precepts and ethical norms, to develop a critical attitude. All of these make a deep mark on the professional profile of the future doctor" (Botti \& Rego, 2010: p. 133).

It is a stage that serves to integrate diverse aspects of knowledge learned in various subjects studied in university courses frequently unrelated to each other. In loco experience enables the student to learn how to assess a situation, work out strategies for facing and finding solutions to challenges, pick out knowledge that is applicable to a situation and use it accordingly.

The Teacher Residency Project presented here draws on medical residency programs to provide recent graduates the opportunity for "immersion" in actual teaching situations, opening up new horizons, complementing their training and establishing ethical and proactive attitudes needed for successful professional performance.

The undergraduate course, as a rule, does not offer the student opportunity to participate in different phases of the teaching process such as preparing classes, teaching materials and instruments destined for evaluation and correction and creating support strategies for especial difficulties. Since these activities are an essential part of the educational process, not having any experience in these sub- 
jects may cause the beginning teacher to feel insecure and sense a lack of savoir-faire needed to deal with such situations.

Studies have shown that during the initial teaching period, the phenomenon known as "transition shock" (Marcelo, 2012; Zabalza, 1994) or "reality shock" in the words of other authors (da Silva, 1997; Huberman, 1992; Veenman, 1984) may occur. This makes this period prone to bring about lack of motivation (Feiman-Nemser, 2001, 2003), malaise (Gold \& Roth, 1993) and frequently, discouragement (Darling-Hammond, 2000) which may trigger teacher attrition teachers leaving teaching (Ingersoll \& Strong, 2011).

The different opportunities for action and exposure to various kinds of activities help the resident to address the various conflicts and tensions present in this initial phase. Beach and Pearson (1998) categorize these tensions and conflicts into four types. The first is that of curriculum and instruction conflicts between the learned concepts and theories and the classroom realities, between the educational proposals and conditions to enforce them.

Then come the conflicts of role, including those inherent to the self-image and the image to be shown as a teacher. They include internal conflicts and ambiguities regarding the transition from student to teacher. Teachers beginning their careers, or even those operating in the classroom on initial training, experience problems with the ambiguity of being in a transitional position, between student and teacher. Beach and Pearson (1998) emphasize the unrest between being a friend of the students or an authority figure.

The third conflict, of interpersonal relationships, concerns the social relations with others agents in the school community: students, faculty, staff, administrators-and the difficulties of living tensions with different groups of students in the classroom or even of isolation from other members of the teaching community.

The fourth type of conflict is the contextual or institutional, which arises from the difference between the expectations carried to the school environment and what, in fact, is institutionally allowed or expected. While coming from their training courses with a mission to be agents of change, the young teachers face standards and a school culture that restrict actions and hamper dreams and educational projects.

Within the Residency Program, not only the projected activities, but also the pairing with experienced teachers, bring opportunities for reflection and discussion of problems, conflicts and experiences of all kinds. This provides a space for the understanding, mitigation and resolution of these conflicts and tensions.

As an instrument to deal with transition difficulties, PRD constitutes a Third Space in which academic training is not the only source of knowledge needed for teacher training. University-acquired knowledge added to that acquired through experience makes for a less hierarchical structure, thus providing the resident with new opportunities for learning. In the words of Gutierrez (2008) it is "a space for transformation, where the potential for expanded forms of learning and for the development of new forms of knowledge is heightened".

Finally, another important factor for successful learning during the Residency 
period is the opportunity given to student teachers to learn about metacognition processes, through which the resident teacher acquires technical and relational know-how that contributes to his gradually taking on responsibility for his professional actions (Betti \& Rego, 2010, 138).

\section{An Experiment in a Distinguished School}

It follows from the above discussed that a successful Residency Program should be implemented in fertile ground-that is to say, beginning teachers need to work in an environment that is favorable to growth. Such an environment must include a well-structured school ambience with clearly defined levels of success, infrastructure that is open to innovative projects, successful school traditions—and perhaps above all—competent professionals who are skilled in sharing, leading, motivating and interacting, with the ultimate aim of building new teaching practices.

CPII is recognized by civil society and by academic and governmental communities as an institution possessing the attributes described above. It is a federal public school consisting of 14 campuses located in diverse regions of the State of Rio de Janeiro. Its approximately 14,000 students are enrolled in Elementary School and High School. Its teaching staff of 1000 teachers has high academic qualifications. Most of them possess the title of Educational Specialist. Almost half of them have Master or PhD's degrees. The school is recognized as a school of excellence that strongly fosters intellectual growth and the development of citizenship values in children and adolescents.

Parallel to PRD, CPII has also set up a Professional Graduate Course leading to a M.Sc. degree on Basic Educational Practices. This provides an academic investigation ambience for teaching practices of the same sort as that intended in what is thought as a Third Space. It follows naturally that PRD students show interest in enrolling in the Master's Course. Some of them have applied and have been accepted also as students in that course.

PRD is made up of a series of activities, some of which actually go beyond school limits. This paper intends not only to describe how this innovative teacher training program was implemented but also to encourage other schools of excellence to adapt the program to their particular needs and resources and to implement similar practices, thus contributing to the advancement of basic education.

\section{The Pilot Project}

The central idea of this project as well as its terminology is consistent with the CAPES Program for Teachers with Supervised Training Periods in a Residency Program for Recent Graduates proposed in 2004 within the framework of Prodocencia, an initiative aimed at drawing up a residency program for teachers similar to medical residency programs. This program, however, was not implemented at the time it was proposed. PRD at CPII emerged from meetings between CAPES and CPII, both interested in developing projects that would pro- 
vide complementary training to new public school teachers in Rio de Janeiro.

The resources that CAPES could provide allied to the willingness of CPII to contribute to the training of new teachers carried out within the concepts presented and discussed in this paper have resulted in the realization of this program. Focused on developing autonomy, producing and applying teaching strategies, absorbing precepts and norms, stimulating critical thinking about teaching practices, the program has been conceived with the purpose of integrating research, theory and practice, with the final objective of helping beginning teachers acquire better qualifications needed for the secure practice their profession.

Several objectives served as the basis for the project. Among them rise:

- To contribute to the improvement of beginning teachers' performances in a public school environment and the competent use of professional knowledge and information acquired in their university courses.

- To develop teaching strategies applicable to the real-life conditions in their home schools (the schools where they actually teach).

- To enable participants to share their knowledge with others in their home schools.

- To create academic products related to teaching practices that can be used in public school conditions.

Based on these ideas and with the help of CAPES study grants made available to all program participants, residents who comply with all of the Program's requirements are awarded certificates giving them the title of Specialist in Basic Education in Mathematics, Chemistry, Biology, History, etc. (subject). The Program, therefore, constitutes a post-graduate (latosensu) course that is different from usual specialization courses in that it is not limited to subjects or modules in which students just observe classes given by experienced teachers. The Program's basic underlying idea is that of the resident's total participation and action in situ as instruments of learning.

To provide information to the Program's target-audience, agreements have been signed with State and District Education Offices in Rio de Janeiro. These offices divulge the Program to those interested in taking part in it-mainly teachers undergoing continuous training. Meanwhile, experienced CPII teachers in Elementary School and High School levels with high-level teaching performances were selected to act as supervisors or mentors, and as coordinators in their fields of teaching. Taking into consideration the number of participating departments and the number of public school teachers interested in the Program, it was initially implemented in the seven areas in Table 1.

\subsection{Participants and Their Roles}

In consonance with the project's structure, PRD participants were classified into four categories according to requisites and main functions.

Resident teachers: The program's target audience, consisting mainly of State and District public school teachers, especially in schools with low Educational 
Table 1. Areas covered in the PRD-CPII pilot project (2012).

\begin{tabular}{cc}
\hline Area & Subjects \\
\hline I & Mathematics \\
II & Biology, Physics, Chemistry \\
III & Portuguese \\
IV & Spanish, English \\
V & Geography, History \\
VI & Sociology \\
VII & Physical Education \\
\hline
\end{tabular}

Development (IDEB) rating, who have university degrees in Education and who were teaching (in 2012) any of the subjects in Table 1 to students from the 6th grade Elementary School up to 3rd year High School.

Supervising teachers: Teachers belonging to CPII teaching staff with (at least) a certificate as Education Specialist and having taught for a minimum of three years at the School. They work with resident students in their respective campuses, counseling, supervising and assessing resident teacher activities. They also help and give suggestions in organizing activities to be done at the resident teacher's home school.

Area Coordinators: Members of the CPII teaching staff with Master's or Doctor's degrees and at least three years teaching experience in the institution. They are experienced teachers who have proved their competence in the classroom and in other academic activities. After consulting the Institution Coordinator and his team, they are responsible for determining Program guidelines. They work in conjunction with supervising teachers to decide what studies and practices are to be done by resident teachers within the scope of CPII as well as in their home schools.

Institution Coordinator: A CPII teacher with a Doctor's degree assigned to the Vice-Rector's Office for Research and Post-graduate Studies. He is responsible for the overall organization of PRD and acts as the Program's spokesman to interested parties. He may provide relevant information and figures when solicited.

The Program's structure with respect to participants and government institutions is shown in the following figure (Figure 1):

It is important to point out that the initial Program outline was drawn up by the CPII teaching departments. It included the selection of teachers who were to be Area Coordinators and Supervisors. This was deemed necessary because of the need to integrate regular day-to-day teaching activities with the teaching-learning processes going on in the different CPII campuses.

During the pilot stage in 2012, there were 67 resident teachers and 20 supervisors working in 7 areas, aside from 7 area coordinators and 1 institution coordinator. Area coordinators and supervisors, with the collaboration of the management team at the Vice-Rector's Office for Research and Post-graduate Studies were given the task of working out Project details. 


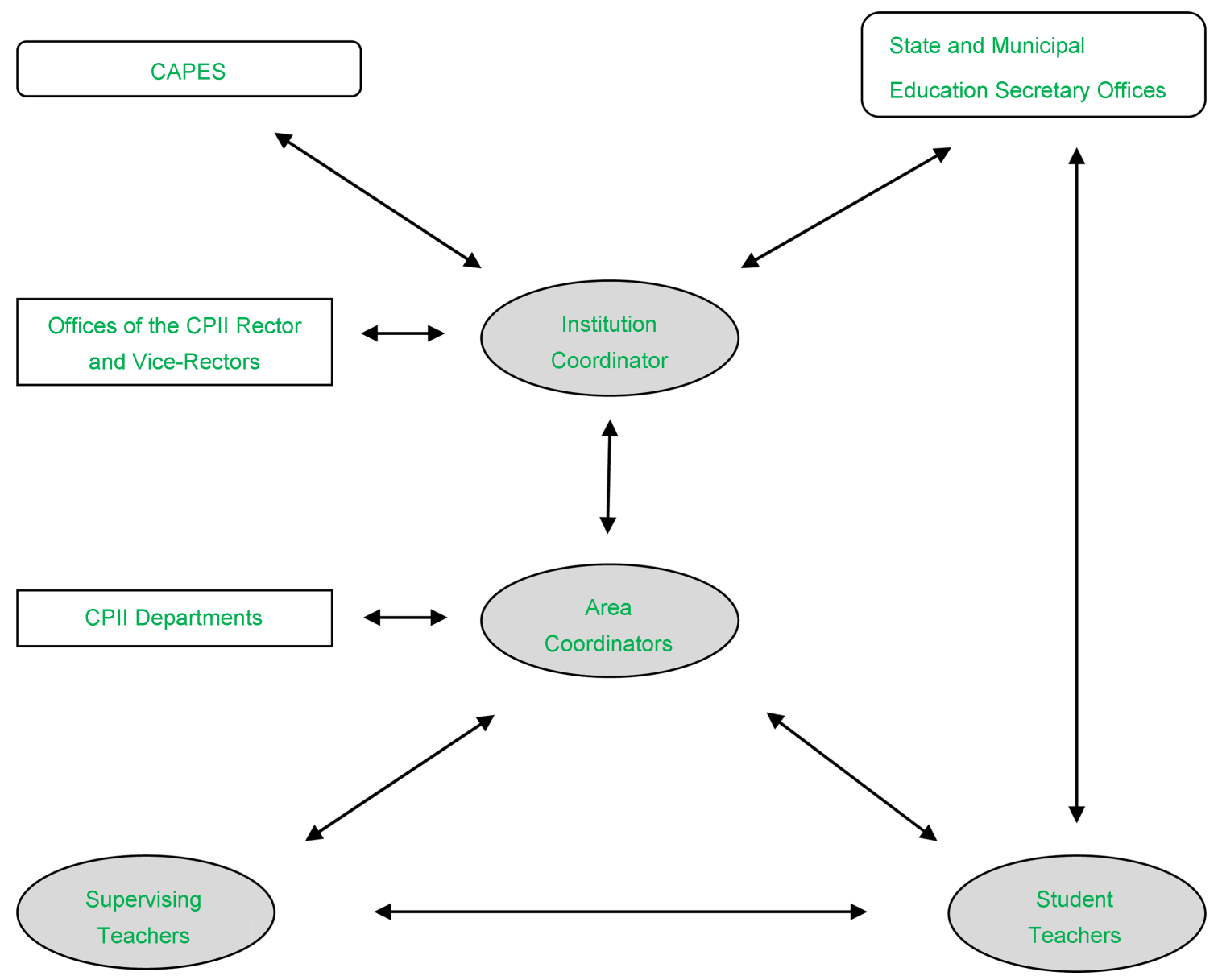

Figure 1. Interaction between participants and agencies involved in PRD.

\subsection{Project Activities}

Although PRD had been drawn up based on solid foundations and a well-defined structure, it is supposed to be constantly redesigned to meet the demands for improvement in the quality of education in Brazil. Based on the tripod of theory, research and practical experience, the project took shape and is being consolidated by the formation of new groups of resident teachers.

The total course workload is one school year during which the resident teacher is involved in school activities (face-to-face or at distance). These activities may include those developed in the school where the resident teacher is allocated in the State or District System. Most of the resident teacher's training occurs within the school space and is dependent on it. These features make PRD similar to medical residency programs in that residents are given the opportunity to work under real-life working conditions.

Aimed at providing the resident teacher with a wide-based training, the Program gives residents the opportunity to observe, participate and interact with all the parts that make up the school structure - Library, Counseling, School Offices, School Support Resources for Students with Special Needs, among others. Thus the resident acquires better qualification, not only in activities that are inherent to his field of knowledge and relevant to teaching practices, but also in 
relation to the whole school structure, providing him with instruments for reflection and for adapting acquired knowledge to real classroom conditions.

With this in mind, program activities have been divided into 3 groups-areas which complement and interact with each other, see Figure 2. They are based on the three basic areas of knowledge required for teacher training - knowledge of the students, knowledge of the subject and knowledge of teaching practices (Shulman, 1987; Veal \& MaKinster, 1999; Tardif \& Raymond, 2000).

Described below are the types and variety of activities to be done in each area.

Teaching activities (corresponding to $65 \%$ of the total workload):

Observing, collaborating, and giving classes in the resident's particular subject or in other area related subjects in the presence of a CPII teacher; taking part in school-developed projects and complementary activities; drawing up lesson plans; supervising directed group studies; taking part in technological or cultural visits with students; preparing teaching material to be used by students with special needs; taking part in discussion groups about evaluating books and public examinations in the resident's line of study; taking part in educational meetings; preparing and putting into practice educational activities in the home school, based on conclusions derived from CPII activities; making periodic reports on activities carried out in the home school, including pictures, teaching material employed, etc.; evaluating activities developed in the home school (to be done in collaboration with the supervising teacher); designing and presenting an academic-educational product related to teaching practice, to be called Final Product, under the guidance of the supervising teacher and to be assessed by a Program committee.

Activities in educational-administrative sectors at CPII (corresponding to roughly $10 \%$ of the total workload):

Learning about SESOP (Supervision and Educational Guidance Division)-its objectives, how it works and is organized, about the School Library, the School Secretary's Office, the IT Laboratory. These activities are aimed at making the resident realize the importance of the proper functioning of these sectors to his or her academic and personal life.

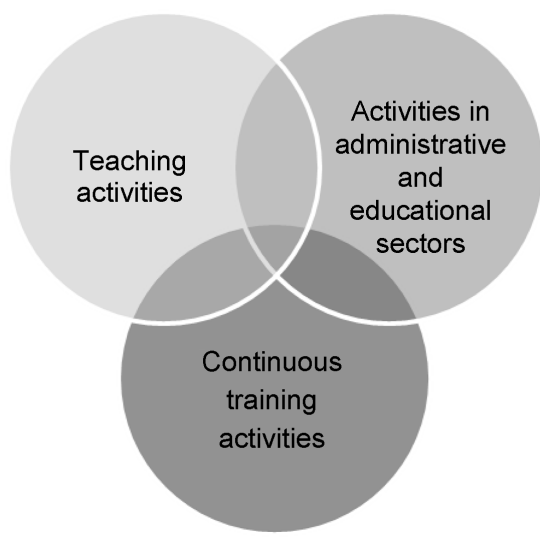

Figure 2. Distribution of PRD resident teacher activities. 
Continued training activities (corresponding to roughly 25\% of the total workload):

Taking part in workshops, attending lectures, "pocket" courses and academic events that require the resident's total or partial presence; preparing a report (at the end of the first semester) on activities executed during this period; preparing an account (at the end of the school year) of the experiences as a Program resident, not only of the activities executed over the year but also including a critical assessment of the resident participation, highlighting positive aspects of the experience as well as giving suggestions for improvement, pointing out the academic areas in which professional growing was experienced, giving detailed information on how they may have contributed to future professional practice.

It is important to point out that most of the workshops held for residents (included in the third group of resident activities described above) are led by qualified CPII teachers, although in some cases, teachers from other schools are invited to lead the workshops. Aside from workshops dealing with specific subjects aimed at advancing subject matter knowledge, that is, "What to Teach" in the terms used by Schulman (1987), a series of workshops on topics of interest to all residents was organized with the aim of sharing and integrating experiences among residents of different areas of study. In these workshops, considerations were made with regard to Schulman's perspectives: "how to teach", "who we teach" and especially on "why teach what the curriculum requires".

Resident activities have been distributed over the Program's 500-hour workload with reference to organization as well as to the availability of time and venues for these activities to take place, providing for a diversity and balance of activities to be carried out over the school year. Several factors were taken into account: the number of hours spent in CPII spaces and in the residents' home schools and their participation in activities that do not require full presence. The resident is required to take part in teaching and administrative activities at least two shifts a week and one a week for activities related to continued training workshops, lectures, etc.

It must be pointed out that the Program calls for the resident teacher to spend about 100 hours in home school activities, where he must execute projects drawn up in the PRD. This bridge between home school and CPII activities is essential for the Program to achieve its goals. By putting to use PRD-acquired knowledge in their home school classrooms, the resident teacher has the opportunity to experiment, assess and reformulate concepts, exercises and processes, enabling him to grow as a teacher and to update his teaching practices. In order to ensure greater efficiency in these actions, he can count on guidance from his supervising teacher with whom he also shares the task of assessing what has been accomplished.

\subsection{Strategies for Gauging Results}

It is widely agreed that the assessment of the results obtained in professional development processes that aim to improve actions and broaden knowledge is an 
integral part of any project. In PRD, three events (in the broad sense of the word) were conceived, all with the aim of keeping track and registering activities done by residents in various fields, evaluating the project's impact on professional growth and obtaining the resident's view of the program as a whole. This information is then used to make improvements in the program the next year it is implemented. It furnishes assessment data about the resident's evolution and the results obtained over, and at the end of, the residency period.

Strategies and resulting assessments reflect the resident's viewpoint and are then submitted to supervisors, area coordinators and administration teams for further appreciation. It is then possible to comply with the suggestions given by Patton (2008: p. 39) to make use of the assessment of activity results in order to provide information regarding the Program's effects (intended and not intended) with the aim of reducing uncertainties, improving efficiency and providing data for decision-making.

The three formal PRD assessment instruments are: the Semester Report, the Final Program Report and the Final Product.

\subsubsection{Semester Report}

This is an account of the resident's experiences over the first semester - his activities at CPII and in his home school, checked and evaluated by his Supervising Teacher and countersigned by the Area Coordinator. It serves as a basis for the Final Program Report.

\subsubsection{Final Program Report}

This is an account of the resident's experiences over the school year, not only about the activities he took part in, but also an evaluation and a critical view of the Program as a whole, highlighting the positive points in his experiences, giving suggestions for improvement, mentioning in which areas he feels he has grown professionally and their particular contributions to his future teaching practice. It should also include critical observations about his Program Diary in which are registered the activities executed during the day together with critical observations about these activities. The Program Diary was introduced to residents during an initial workshop and constitutes a must for all residents. It should serve as the basis for keeping track of and assessing the residency program. Supporting papers, photographs, teaching material made up and/or used in Program activities should be attached. Together, they make up a portfolio of the activities carried out during the whole Program, enabling Supervisors and Coordinators to make a joint assessment of the resident's performance.

\subsubsection{Final Product}

The Final Product has to do with teaching practices employed in elementary or high school levels and is prepared under the Supervisor's guidance. It comes with a monograph that sets the context for the product. The format of this written work includes an introduction containing the reasons that led the author to write it, the target audience and prerequisites (if any), followed by a list of objectives and a description of teaching methodologies to be employed, together with 
the theoretical basis for these methodologies. An important requirement calls for the application of the product in the resident's home school during his residency period and should include an evaluation of the product's suitability, efficacy and efficiency in achieving expected goals.

Each resident's teaching Product is evaluated by a committee of three teachers, comprising one teacher-participant in the resident's teaching field (Supervisor or Area Coordinator) and two teacher-participants in other teaching fields. The products are presented in public so that they could be shared with Program participants and the public in general.

The teaching products presented by now revealed the wealth of experiences that residents had during the Program. It is clear that the resident teachers made use of theoretical viewpoints, of teaching techniques and strategies that were previously unknown to them or others they hesitated before to make use of. They were also encouraged to adapt or create new ways of teaching and counseling students. Here are some examples of residents' papers in various fields: A Project for Learning Elementary Mathematical Concepts in (now extinct) Basic-level Courses Using Geogebra Software; Using Blogs in Physical Education Classes; The Use of Literature in Teaching History: a Perspective Arising from the Comparison of Two Different Teaching Practices; The Family Tree: Learning about Ethnic Origins and Eliminating Racism in Schools; Board Games: the Protectors of Nature. All the products are left available at the Graduate Programs Library.

Below are excerpts of some residents' Final Program Reports. There can be found expressions that reveal the anguish generated by conflicts and tensions inherent in the early teaching career, as described by Beach and Pearson (1998). Various memorials highlight that these conflicts are minimized or resolved in the Third Space created, the extensive site training establishing interfaces between academia and school reality, between practical experience and theoretical formulation and between concepts and practical experience.

"A lot has been said and I still have a lot to say. The experiences I have been through and the lessons I have learned during the Residency Program would certainly not fit within the Final Program Report. There are forms of learning that cannot be expressed in concrete terms that cannot be put into words, even if we know they exist and enrich our lives".

"Finishing one more stage in the Residency Program signifies the beginning of a new phase in my professional trajectory, seen in the light of new perspectives. I now see an increasingly endless horizon of possibilities in education. I believe that the ideas I have learned in the Residency Program are viable in real-life teaching situations due to the importance given to experience in real teaching practice. The residency program helped me to find the guiding light I needed for reflecting on my professional life. Sharing experiences with fellow residents and the advice given by CPII teachers were essential to the process of adding more knowledge (theoretical and practical) to my five years' experience as a teacher". 
"Coming to the end of my residency and having only one requirement to comply with (the Final Product), I find myself filled with daring, sometimes blown-up, intentions of sharing what I have learned in the Residency Program with my colleagues who, like me, especially during our initial years of teaching, have been assailed by the feeling that 'something is lacking'-experience, maybe, a feeling of security, practical knowledge of day-to-day teaching-needs that teacher training courses do not successfully meet".

"The PRD ... signified a lot to my professional life in view of the fact that the high-quality work in education done by CPII teachers has served as a guideline for my professional development and critical thought. I had come to this conclusion at the end of the first semester; nevertheless, having reached the end of the Residency Program, I have something more to say: this program is absolutely essential, especially for many beginning teachers who are beset by doubts, fears and feelings of insecurity. The Program's emphasis on real teaching practices and the development of critical thought was essential to my professional growth. Observing classes and class activities, attending workshops and meetings with experienced teachers opened new doors for teaching students not only in my home school but for all the students I may have in the future".

"The workshops, lectures and seminars contributed a lot to my professional development and made me reflect on my teaching practices. The course has changed me as a professional. Observing classes and receiving suggestions from more experienced teachers encouraged me to reach out beyond the limits of 'my' classes".

"I would like to congratulate and thank everyone, Coordinators, Supervisors, Masters and Doctors who helped me over my residency course to write this Final Report. The Program contributed immensely to my professional growth. It should be replicated in other educational institutions since it fosters interaction and union between educators and students. On finishing this course, I feel I have taken a big step in understanding and realizing my responsibility as an educator. Seeking new methodologies and technologies to be used in teaching-learning processes is the obligation of every teacher and educator".

The categories of Beach and Pearson (1998) can be identified in these fragments. The anxieties and tensions of the early years of professional practice can be found there, at the same time we can see how they find in the experience ways to resolve such conflicts. The experience in different school situations, together with the sharing of teaching practices with more experienced peers, brings new ideas and different perspectives. The reports also demonstrate how the program instigates investigative postures and confidence in the change of attitude that makes it socio-historically contextualized and helps the professional to move forward to effective educational practice.

The concept of Third Space (2010) helps to recognize in their words the search for better construction of his professional career. The convictions at- 
tained by the residents about their achievements translate what is proposed in the Program to constitute a Third Space in Education. The Residents show how they have experienced the integration of conceptual issues to the development of specific solutions to the contexts of their professional activities, by developing educational constructs that combine disciplinary concepts. They make clear how this develops in the educator a critical view of the school reality and the needs of the agents of the teaching-learning process. They emphasize how, by offering the resident partnership with more experienced teachers during school experiences and sharing teaching actions and creating different spaces for reflection, action, creation and self-assessment, PRD gave them conditions to intertwine theoretical foundation and application in educational settings.

The reports also show how PRD develops in the educator a critical view of the school reality and the needs of the agents of the teaching-learning process, understanding, analyzing and developing creative responses to the nodes of learning. The experience in different school situations, together with the sharing of teaching practices with more experienced peers, brings new ideas and different perspectives. So the reports highlight the pillar of research in the framework of the Third Space-based interaction of the pillars of theory, practice and research. The Program makes residents aware of the duty to seek new methodologies and technologies for improvement of education.

\section{Expectations and Adjustments}

The success of the PRD Pilot Project in 2012 led to the implementation of a more comprehensive program in 2013. Based on the experience acquired in 2012, PRD-2013 continues the process of building more democratic and efficient teaching strategies and improving the efficacy of activities carried out in the Program.

Considering the impact and the results obtained by the Program, CAPES agreed to increase the number of scholarships by $80 \%$ in relation to PRD-2012. This increase came about as a result of an evaluation of the effects of PRD-2012, made according to the parameters determined by Antheiul et al. (1986): the participants' reaction, what they learned, to what extent they succeeded in making use of theoretical knowledge in actual teaching practice, and its impact on program organization. Based on the reaction of the participants, of the funding agent, of CPII as a whole, and especially on the participants' change of attitude towards teaching as described in their Final Program Reports, it was demonstrated that the results were very positive, considering all four aspects of the evaluation.

A more comprehensive Program required adjustments, the most important being the addition of several subjects such as French, Philosophy, Visual Arts, Drawing and Music. Another adjustment called for the inclusion of a teaching area which would involve teachers working in lower elementary school grades. It has been observed that there is a considerable group of teachers working in initial elementary school grades who are eager to acquire better teaching qualifica- 
tions. CPII, which opened its doors to students in this age range in the 1980s and has done cutting-edge work in this academic phase with very successful results especially in literacy teaching, has plenty to share, with regard to experience and successfully tested teaching practices. CPII teachers working in this segment were also eager to take part in the Residency program and promptly answered the call for supervising teachers and area coordinators.

The new area is certainly complex and hybrid in nature. It focuses on the beginning grades in elementary school, usually referred to as basic education grades where students acquire literacy and numeracy skills and are introduced to natural and social sciences, aside from forms of artistic and physical expression. Since the area deals with processes involving cognitive maturation in children during the beginning years of school, the especial needs of this area must be met by those who have had especial training in doing so. CPII teachers who work in these grades possess these qualifications, not only because of the group's collective experience but also by the fact that most teachers in this group are holders of MSc or PhD degrees.

Other changes-academic or organizational-were also affected. As there was an increase in the number of Program participants, measures were taken to ensure that Program activities were carried out properly without disturbing the normal educational processes in the schools where the residents did their work. To this end, residents were assigned to different CPII campuses as evenly as possible, so as to cover a bigger geographic space, thus promoting more interaction between residents and supervisors. Contact with professionals in these campuses has enabled residents to gain new attitudes and other forms of knowledge.

It also became necessary to make changes in the distribution of Program activities in order to meet the needs of the target audience-recent graduates teaching in municipal or state schools that received a low Educational Development (IDEB-Índice de Desenvolvimento de Educação Básica) rating. Changes were made based on suggestions and comments given by Pilot Program participants. One of these is a decrease in the work load to 420 hours, making it possible to fit the Program in the space of one school year. Since it was deemed that this change would affect neither the Program's final results nor its objectives, it has been incorporated into the program's structure. More emphasis is now given to academic-teaching activities.

\section{Conclusion}

The Teacher Residency Program at CPII is a model for a continuing program for teacher training, providing a Third Space in the educational field. It aims not just to provide a link between theory and practice but to integrate conceptual issues of teaching practices with the cognitive development of teaching constructs in the light of established concepts regarding the subject in question. These enable the resident to develop a critical point of view concerning real school conditions and also the needs of learning-process agents. 
The experience in different school situations, together with the sharing of teaching practices with more experienced peers, brings new ideas and differentiated perspectives. A space that allows for constant reflection, action, creation and self-assessment supports the development of abilities to understand, analyze and work out creative solutions to the actual conflicts experienced by resident teachers in their teaching practice.

The PRD actions such as meetings with peers, participation in workshops, elaboration of interdisciplinary projects and joint assessments provide the teacher resident a practice with theoretical support of more experienced peers academically and professionally. The residents' immersion in the research groups of the CPII Professional M.Sc. Program on Basic Education Practices provides a focused academic research environment for typical practice of what is conceived as Third Space.

Partnership with more experienced teachers during school experiences and share of teaching practices gives opportunity for the resident to develop conditions of critical thinking, pedagogical experimentation, and integration between the theoretical basis and its application in the educational context. These conditions instigate also investigative postures and confidence, enhancing the transformation of thoughtless repetition of attitudes into systematic and reasoned reflection, fundamental for the historically contextualized presence appropriate to effective education. The framework established, with activities in the areas of teaching and administration, facilitates the integration of heterogeneous and plural knowledge, associating the knowledge of the subjects, the curriculum, the vocational training and the experience.

The experience at CPII reflects in the residents, not as a model to be emulated and repeated, but as a set of experiences, experiments and observations that can generate a critical stance and the maturity to identify and select what they can incorporate into their own living experience as a teacher, to meet the challenges of their daily lives and to create their own style of teaching that leads to higher success rates in the teaching-learning process.

\section{Acknowledgements}

The authors are grateful to the support of Coordination for the Improvement of University Level Personnel (CAPES) - Ministry of Education of Brazil and Special; thanks to the professors and leaders of the Colégio Pedro II. Special thanks to Dr. Silvia Becker, who contributes greatly to this work and is no longer with us.

\section{References}

Antheiul, J. H., \& Casper, I. G. (1986). Comprehensive Evaluation Model: A Tool for the Evaluation of Nontraditional Educational Programs. Innovative Higher Education, 11, 55-64. https://doi.org/10.1007/BF01100109

Beach, R., \& Pearson, D. (1998). Changes in Preservice Teachers' Perceptions of Conflicts and Tensions. Teaching \& Teacher Education, 14, 337-351.

Bhabha, H. K. (1994). The Location of Culture. London: Routledge.

Bhabha, H. K. (Ed.) (1990). National and Narration. London: Routledge. 
Botti, S. H. O., \& Rego, S. (2010). Teaching-Learning Process in Medical Residency. Brazilian Journal of Medical Education, 34.

Brasil Ministry of Education (2007). The Education Development Plan. Reasons, Principles and Programs. Brasília, DF: MEC. http://portal.mec.gov.br/arquivos/pdf/livromiolov4.pdf Accessed in 22/06/2017

Bullough, R. V., Draper, M. J., Smith, L., \& Burrell, J. (2004). Moving beyond Collusion: Clinical Faculty and University/Public School Partnership. Teaching and Teacher Education, 20, 505-521.

Bullough, R., Hobbs, S., Kauchak, D., Crow, N., \& Stokes, D. (1997). Long-Term PDS Development in Research Universities and the Clinicalization of Teacher Education. Journal of Teacher Education, 48, 85-93. https://doi.org/10.1177/0022487197048002002

Cochran-Smith, M., \& Lytle, S. L. (1999). Relationships of Knowledge and Practice: Teacher Learning in Communities. Review of Research in Education, 24, 249-305. https://doi.org/10.2307/1167272

Cornbleth, C., \& Ellsworth, J. (1994). Teachers in Teacher Education: Clinical Faculty Roles and Relationships. American Educational Research Journal, 31, 49-70. https://doi.org/10.3102/00028312031001049

da Silva, M. C. M. (1997). The First Year of Teaching: The Clash with Reality. In M. T. Estrela (Org.), Living and Building the Teaching Profession (No. 26, pp. 51-80). Porto: Porto Editora, Coleção Ciências da Educação.

Darling-Hammond, L. (2000). Solving the Dilemmas of Teacher Supply, Demand, and Standards: How We Can Ensure a Competent, Caring, and Qualified Teacher for Every Child. National Commission on Teaching \& America's Future.

Darling-Hammond, L. (2009). Teacher Education and the American Future. Charles W. Hunt Lecture. Presented at the Annual Meeting of the American Association of Colleges for Teacher Education, Chicago, February 2009.

Feiman-Nemser, S. (2001). From Preparation to Practice: Designing a Continuum to Strengthen and Sustain Teaching. Teachers College Record, 103, 1013-1055. https://doi.org/10.1111/0161-4681.00141

Feiman-Nemser, S. (2003). What New Teachers Need to Learn. Educational Leadership, 60, 25.

Gallas, K. (2004). Look, Karen, I'm Running Like Jello: Imagination as a Question, a Topic, a Tool for Literacy Research and Learning. In C. Ballanger (Ed.), Regarding Children's Words: Teacher Research on Language and Literacy (pp. 119-148). New York: Teachers College Press.

Garrido, E., \& de Carvalho, A. M. P. (1999). Reflections on the Practice and Qualification of Initial Teacher Training. Research Copybook, 107.

Gold, Y., \& Roth, R. A. (1993). Teachers Managing Stress and Preventing Burn-Out: The Professional Health Solution. London: Falmer Press.

Gutierrez, K. (2008). Developing Sociocultural Literacy in the Third Space. Reading Research Quarterly, 43, 148-164. https://doi.org/10.1598/RRQ.43.2.3

Huberman, M. (1992). The Professional Life Cycle of Teachers. In A. Nóvoa (Org.), Lives of Teachers (2nd ed., pp. 31-61). Portugal: Porto Editora.

Ingersoll, R., \& Strong, M. (2011). The Impact of Induction and Mentoring Programs for Beginning Teachers. Review of Educational Research, 81, 201-233. https://doi.org/10.3102/0034654311403323

Labaree, D. (2004). The Trouble with Ed Schools. New Haven, CT: Yale University Press.

Marcelo, C. (2012). Starting off Right: Teaching Insertion of Beginning Teachers. Ponta Grossa, 15, 209-221. 
http://www.revistas2.uepg.br/index.php/olhardeprofessor/article/view/4360/3258 Accessed in 22/06/2017

Moje, E. B., Ciechanowski, K. M., Kramer, K., Ellis, L., Carrillo, R., \& Collazo, T. (2004). Working toward Third Space in Content Area Literacy: An Examination of Everyday Funds of Knowledge and Discourse. Reading Research Quarterly, 39, 38-70.

https://doi.org/10.1598/RRQ.39.1.4

Patton, M. Q. (2008). Utilization-Focused Evaluation (4th ed.). Thousand Oaks, CA: SAGE Publications, Inc.

Pointer-Mace, D. (2009). Teacher Practice Online: Sharing Wisdom, Opening Doors. New York: Teachers College Press.

Shulman, L. S. (1987). Knowledge and Teaching: Foundations of the New Reform. Harvard Educational Review, 57, 1-23. https://doi.org/10.17763/haer.57.1.j463w79r56455411

Soja, E. W. (1996). Third Space: Journeys to Los Angeles and Other Real-and-Imagined Places. Malden, MA: Blackwell.

Tardif, M., \& Raymond, D. (2000). Knowledge, Time and Learning of Work in Teaching. Educação \& Sociedade, 21, 209-244.

http://www.scielo.br/scielo.php?script=sci_arttext\&pid=S0101-73302000000400013\&ln $\mathrm{g}=\mathrm{pt} \& \mathrm{nrm}=\mathrm{iso}$

Valencia, S., Martin, S., Place, N., \& Grossman, P. (2009). Complex Interactions in Student Teaching: Lost Opportunities for Learning. Journal of Teacher Education, 60, 304-322. https://doi.org/10.1177/0022487109336543

Veal, W. R., \& MaKinster, J. G. (1999). Pedagogical Content Knowledge Taxonomies. Electronic Journal of Science Education, 3. http://wolfweb.unr.edu/homepage/crowther/ejse/vealmak.html

Veenman, S. (1984). Perceived Problems of Beginning Teachers. Review of Educational Research, 54, 143-178. https://doi.org/10.3102/00346543054002143

Vick, M. (2006). "It's a Difficult Matter" 1: Historical Perspectives on the Enduring Problem of the Practicum in Teacher Preparation. Asia-Pacific Journal of Teacher Education, 34, 181-198. https://doi.org/10.1080/13598660600720579

Williams, J. (2014). Teacher Educator Professional Learning in the Third Space: Implications for Identity and Practice. Journal of Teacher Education, 65, 315-326. https://doi.org/10.1177/0022487114533128

Zabalza, M. A. (1994). Diários de aula. Porto: Porto Editora.

Zeichner, K. (1996). Designing Educative Practicum Experiences for Prospective Teachers. In K. Zeichner, S. Melnick, \& M. L. Gomez (Eds.), Currents of Reform in Preservice Teacher Education (pp. 215-234). New York: Teachers College Press.

Zeichner, K. (2002). Beyond Traditional Structures of Student Teaching. Teacher Education Quarterly, 29, 59-64.

Zeichner, K. (2010). University-Based Teacher Education: Rethinking the Connections Between Campus Courses and Field Experiences in College- and University-Based Teacher Education. Journal of Teacher Education, 61, 89-99.

https://doi.org/10.1177/0022487109347671 
Submit or recommend next manuscript to SCIRP and we will provide best service for you:

Accepting pre-submission inquiries through Email, Facebook, LinkedIn, Twitter, etc. A wide selection of journals (inclusive of 9 subjects, more than 200 journals)

Providing 24-hour high-quality service

User-friendly online submission system

Fair and swift peer-review system

Efficient typesetting and proofreading procedure

Display of the result of downloads and visits, as well as the number of cited articles Maximum dissemination of your research work

Submit your manuscript at: http://papersubmission.scirp.org/

Or contact ce@scirp.org 